\title{
SECURITIES ASPECTS OF SPECIALIZED FINANCING
}

\author{
BRUCE R. LIBIN*
}

This paper reviews the securities aspects of specialized financing that is, increasingly, required to mount the capital-intensive projects being undertaken by the oil and gas industry. It reviews selected aspects of securities law, and factors to consider in the utilization of the "quasi-equity" securities of joint ventures, "deduction flow-through" share offerings, and limited partnerships.

\section{INTRODUCTION: EQUITY SOURCES; "QUASI-EQUITY"}

One of the few things that the governments of Alberta and Canada appear to agree on in their discussions/negotiations over pricing formulas for Alberta oil is the enormous quantities of capital that will be required during the coming years to finance the expansion of the petroleum industry and the exploration for and development of reserves of oil and gas. These amounts, running into many, many billions, will come from a variety of sources, both domestic and foreign, and in a variety of forms. Bank and government financing will lead the way for tangible items and the development of the necessary infrastructure: witness the bank commitments for the financing of the pre-build of the Foothills Pipeline and the provincial direction and support given to the development of the New Town of Fort McMurray. Banks, life insurance compenies, pension funds and other traditional financial institutions can be expected to help finance the development of reserves and to provide much of the capital for the manufacturing end of this business, including tar sands plants and gas processing facilities, as well as refineries.

It is less likely, however, that direct institutional funding will be as readily available to finance the exploration side of the business, the side where risk, the anathema to financial institutions, predominates. Debt, public or private, is available, in some instances, to finance exploration, at least indirectly' but this is likely limited to those companies with a sufficient cash flow from production to service the debt even if all the exploration work undertaken with the proceeds of the debt proves valueless. Accordingly, equity financing, of one type or another, is required to finance exploration activities.

Equity financing can be broken down into five basic categories, varying by source and nature.

(i) Internally generated funds. Retained earnings in a company, being net earnings for a period less dividends paid, whon supplemented by non-cash income statement items, such as depletion, depreciation, amortization and deferred income tares, provide a base of capital available for reinvestment. This, of course, to the extent available, is the primary source of exploration funding, for here a company is risking its own dollars to try to develop an enhanced return on equity. Any time a company does not believe it can do as well for its shareholders by reinvesting these funds as the shareholders can do on their own, it should pay out by way of dividend all available cash. ${ }^{2}$

(ii) Sale of common shares. This method of equity financing, the cleanest and neatest, is probably the most expensive, from a cost of capital point of view. Assuming a

- Solicitor, Bennett Jones, Calgary, Alberta.

1. See e.g. the "Use of Proceeds" soction in the Amoco Canada Petroleum Company Ltd. prospectus dated January 17, 1979, relating to an issue of $\$ 100,000,000$ of debentures.

2. Relevant to this point is s. 91 of The Companies Act, R.S.A. 1970, c. 60, as am., which permits wasting asset companies, subject to certain testa, to pay dividends out of cash flow rather than earnings. 
company is already public, there is no negative information about the company which has not been disclosed to the market place, and the market price of the shares reflects the information which has been disclosed, the limitation is that there is no leverage, or promotion. The sale of a common share will be on roughly the same basis as the market prices of the presently outstanding shares. The purchaser contributes his dollars for a piece of the existing pie and for the anticipation that management can do as well, or better, with the new dollars. To get the new dollars, the existing shareholders must accept a dilution of their existing interests.

This situation varies, of course, for an initial public equity offering in a junior oil and gas company where the share issuance must be viewed from alternative perspectives: from the position of the company and from the vantagepoint of the original shareholders. As analyzed from the place of the issuer, the problem is one of pricing the ahares to be sold. The price must be high enough to warrant the issuing of shares and the incurring of the sizeable transaction costs (time, money, effort, aggravation) together with a readiness to accept the problems inherent in becoming a public company, such as having to deal with securities commissions, public shareholders, etc. Yet the price must be low enough so that the underwriters can sell the issue and the price can be expected to gradually rise, thus keeping the shareholders and the brokers happy. From the position of the existing shareholders, the higher the price, the higher their paper wealth; the lower the price the sooner their shares will be released from escrow.

(iii) Sale of preferred shares. Straight preferred shares, as opposed to convertible preferreds, participating preferreds or other variants, are really just a form of junior or subordinated debt, the return on which, being dividends, receives a different taration treatment under the Income Tar Act' (Canada) than does the interest on ordinary debt. This has two main consequences: the coupon rate will adjust down from dobt in accordance with a tax factor and the coupon rate will adjust up from debt because of the junior nature of the instrument. Because of the corporate restrictions on when companies might pay dividends and because of the junior nature of the instrument, the market generally will require that issuers of preferred shares be mature enough companies so that the preferred shareholders have some reasonable assurance that their dividends will be paid. This means that straight preferred shares are not readily usable by the very junior companies.

(iv) Hybrid securities. Traditional forms of debt and equity can be packaged together in various hybrid forms so as to increase their attractiveness to the market. Examples are convertible debentures (debt instruments convertible into an equity instrument), convertible preforreds (junior debt/senior equity instruments convertible into equity with a participation in profit and growth) and participating preferreds (preferred shares which will share in the future corporate prosperity over and above a fixed coupon rate). Additionally, use can be made of warrants, being instruments representing a call on securities in the future. (Warrants are fired torm securities, usually two to five years but ranging from one to ten years, which provide the holder with the right to subscribe, at a predetermined price, for treasury shares of a company. On subscription, a warrant-holder surrenders his warrant, pays the stipulated price and receives a common share in return. Warrants unexercised at the duration of the term are worthless.) Frequently, securities are sold in packages, usually called "Units", with each Unit consisting of 80 many of Security A and so many of Security B. This way, an attempt is made to meet a broad range of investment objectives of purchases within a single issue. For example, a pension fund may want security of principal, and interest thereon, while seeking a participation in the growth of the issuer. This could be met by issuing units consisting of secured bonds or debentures and warrants to subscribe for com. mon shares. The institution has met its goals, the company has received funds, the

3. R.S.C. 1970, c. 1-5, amas. 
coupon rate on the debt should be somewhat lower because of the accommodation to the lender and the company has deferred diluting its equity until a time when, hopefully, it has employed the proceeds of the debt to generate additional per share profit.

(v) Quasi-equity. If the foregoing techniques prove inadequate to provide the necessary risk capital as equity funding, companies may turn to financing through the use of what may be called "quasi-equity", that is, a committed, permanent base of someone else's capital upon which the company can grow and profit. The concept here is to maximize corporate returns on the existing capital base by developing assets with the capital of others, and then taking a piece of the action. In a sense, the company looking for equity capital finds itself in the position of managing the money of others, for which it receives a return for its efforts, which return is often called a "promotion".

The three vehicles used to raise quasi-equity dealt with here are joint-ventures, limited partnerships and "deduction flow-through share offerings" ("66.3 Companies"). Note that the use of these mechanisms is not limited to small companies. Joint ventures range from the small participation, for example by a few lawyers with a small private company, through large multi-million dollar programs, such as Union Gas participating with Canadian Reserve. Limited partnerships are used from small scale ventures by small companies, to standard use for fund-raising by junior public companies (such as Northstar, Czar, Wainoco), to financing specific exploration projects for large companies (such as the Prince Edward Island farmout by Hudson's Bay Oil \& Gas in the Hydrocarbons 79 Program). Deduction Elow-through share offerings range from the start-ups, such as GenEnergy, to larger companies, such as the Rangeco deal promoted by Ranger Oils, to large companies such as the Beaufort financings promoted by Dome Petroleum. Each of these forms will be addressed later in this paper. But first, a review of the securities acts and how they become of consequence to this group is necessary.

\section{SECURITIES LAWS**}

Securities laws' have a dual objective: firstly, the protection of the investing public, and secondly, the maintenance of stable capital markets. The Alberta Securities Act ${ }^{5}$ (hereafter "The Securities Act") achieves these objectives by providing for the registration of investment dealers and brokers and by requiring that trades ir securities which constitute a distribution to the public be qualified by a written prospectus making full, true and plain disclosure. In the context of securities regulation, the concepts of "security", "trade" and "distribution to the public" are of critical importance. Each of these concepts will now be discussed.

\section{A. What is a Security?}

The definition section' of The Securities Act lists fourteen examples of what constitutes a security, yet this list is by no means exhaustive. The definition is extremely broad and encompasses most, if not all, commercial agreements and instruments. The nature of the definition and the purpose of the Act as a remedial,' rather than a punitive, statute allows the Courts to give the definition a broad and liberal construction capable of dealing with a wide variety of situations. What follows is a brief discussion of the more relevant elements which constitute the definition of security.

-. The writer gratefully acknowledges the substantial contribution made by R.M. Bugoroch wo Section II of this paper.

4. For a more detailed review of the cases in this area see generally David Johnston. Canadien Securities Regulation (Toronto, Butterworth \& Co., 1977) and Victor P. Alboini. Ontario Securities Lau (Toronto. Richard DeBoo Limited. 1980).

5. R.S.A. 1970, c. 333, as am.

6. Id. at s. $2(27)$.

7. The Interpretation Act. R.S.A. 1970, c. 189, s. 11. 
1. "(i) any document, instrument or writing commonly known as a security."

Securities legislation is a perfect illustration of the drafteman finding comfort in ambiguity. What is meant by "commonly known"? The Quebec Securities Commission answered this in $\operatorname{Re}$ John T. Gelderman \& Co. Inc.,' a case which considered whether commodity futures contracts were securities. In ruling that they were not, the Commission said that:

... proof of common knowledge must be based on an overwhelming set of facts and conclusive evidence. On that basis and notwithstanding the fact that they are viewed by the securities industry as speculative opportunities, we are unable to conclude that commodity futures contracts are commonly known as securities in the trade, at the present time.

It is worth noting that under the new Ontario Securities Act which came into force on September 15, 1979,10 commodity futures contracts are securities if they are not traded on a commodity futures exchange recognized by the Ontario Securities Commission under The Commodity Futures Act, 1978."1

2. "(ii) Any document constituting evidence of title to or interest in the capital, assets, property, profits, earnings or royalties of any person or company."

This definition is unusually broad. In $R$. ex. rel. Irwin v. Dalley, Dalley had been granted permits by the Department of Lands and Forests of British Columbia to engage in surface prospecting for Crown oil and natural gas on the understanding that if sufficient work was done and the fees paid he would be granted a drilling licence and thereafter be entitled to a lease of the property.

Without having acquired any leases, Dalley nonetheless conveyed fractional interests in his "rights, title and equity in the ... mineral rights" to various purchasers. It was held by the Ontario Court of Appeal that the accused had "lonowingly" traded in a "security" without being registered as a broker. The permits per se were not securities, but the agreements of sale whereby the purchasers were conveyed fractional interests were documents constituting evidence of title to, or interest in Dalley's property. ${ }^{\text {.9 }}$

The Court extended the meaning of security so that almost any agreement becomes a security since nearly every such document affords evidence of title to, or interest in property. It is submitted that this decision is probably wider than was necessary under the circumstances, since under this interpretation a deed of land could be construed as a security, with the consequence that a real estate broker would be required to be registered as a security dealer. ${ }^{34}$

In Re Ontario Securities Commission and Brigadoon Scotch Distributors (Canada) $L t d .{ }^{13}$ scotch whiskey warehouse receipts were considered to be securities since they were purchased for investment purposes. Hartt J., however, added this important qualification: 10

The definition would not include documents of title which are bought and sold for purposes other than investment, for example, bills of lading and receipts for goods purchased for inventory or consumption purposes. Such an intention on the part of the Legislature can be inferred from the basic aim or purpose of The Securities Act, 1966, which is the protection of the investing public through full, true and plain disclosure of all matorial facts relating to securities being issued.

\footnotetext{
8. (1972) 3 Quebec Securities Commission Weekly Summary No. 65.

9. Id.

10. The Securities Act. S.O. 1978, c. 47, g. $1(1) 40$ xvi.

11. S.0. 1978, c. 48. See also. Alboini, supra n. 4 at 32.

12. (1957) 8 D.L.R. (2d) 179 (Ont. C.A.).

13. Id. at 184.

14. See Alboini, supra n. 4 at 32

15. [1970] 3 O.R. 714 (Ont. H. CL.).

16. Id. at 716.
} 
3. (v) Any bond, debenture, share, stock, note, unit, unit certificate, participation certificate, certificate of share or interest, preorganization certificate or subscription."

This element of the definition is perhaps the clearest and its meaning is self-explanatory.

4. (ix) Any certificate of interest in, or other document constituting evidence of

(A) any lease, reservation or permit of rights to any mineral or minerals, or

(B) a certificate of record of a mineral claim, or

(C) any other instrument granting the right to prospect for, explore for or recover a mineral or minerals, or

(D) petroleum, natural gas or other mineral royalties, or

(E) any fractional undivided interest or other interest in any thing mentioned in paragraphs (A) to (D)."

This definition deals with interests in oil and gas and is of particular importance to the oil and gas industry. Surprisingly, there have been few cases which have interpreted this definition. ${ }^{17}$

5. (xiii) Any investment contract, other than an investment contract within the meaning of The Investment Contracts Act."

This is perhaps the most important branch of the definition since it allows the Courts to characterize financing devices which do not properly fit within any of the above mentioned definitions as investment contracts. A drilling fund, whatever its form, is the quintessential example of an investment contract. The subscribers to the fund rely totally on the management abilities of the promoter to realize a profit. Like much of our securities legislation, developments in the United States have had a significant influence on the jurisprudence surrounding investment contracts.

The characterization of a financing device as an investment contract is based primarily on two tests: the "common enterprise" test, and the "risk capital" test.

The common enterprise test was first enunciated in SEC v. W. J. Howey Co., ${ }^{18}$ a decision of the U.S. Supreme Court.

In that case the Howey Company offered prospective purchasers the opportunity to purchase orange groves. As part of the agreement the purchasers were given the option to purchese service contracts whereby an affiliate of Howey would undertake to develop the groves and market the oranges. The investors, who had neither the expertise nor the inclination to grow oranges, hoped only to realize a profit on their investment. The Court held that the sales of the land together with the service contracts were investment contracts. An investment contract was interpreted to mean any contract or transaction whereby a person invests his money in a common enterprise relying solely on the efforts of the promoter in order to obtain a profit.

The test enunciated in the Howey case was referred to in The Attorney General of Alberta v. Great Way Merchandising Ltd.," a decision of the Alberta Court of Appeal. Great Way proposed to establish a retail discount operation; as part of its promotional campaign, it prepared an agreement called an Authorized Representative Agreement, the objective being to recruit 3,000 such representatives who in turn would each enlist 50 customers for the store. Each representative had the opportunity of being a distributor or a supervisor. The cost was $\$ 450.00$ to become the former, and $\$ 1,010.00$ for the latter. In both cases Great Way would pay sales commission of $5 \%$ and $10 \%$ respectively on merchandise sold to the customers enlisted by its distributors and supervisors. In addition,

17. But see R. v. Bird and International Claim Brokers Limited (1963) 43 W.W.R. 241 (B.C. S.C.), which held that the purchase and sale of mineral claims constituted trading in securities.

18. 328 U.S. 293 (1946) (U.S.S.C.).

19. [1971] 3 W.W.R. 133 (Alte. C.A.). 
$\$ 350.00$ of the $\$ 450.00$ paid by each distributor went towards the purchase of the store's stock-in-trade.

The Court of Appeal held that the Authorized Representative Agreement was an investment contract since the agreement contained provisions for investment and promised a return to the investor. It was irrelevant that the investment provisions were intermingled with others of a non-investment nature, since the obvious purpose and effect of the Agreement was that of an investment contract. The importance of this case lies in the Court's willingness to look to the substance of a transaction rather than to its form.

The Howey case has been criticized for imposing a standard which is vague and difficult to apply..$^{20}$ A marked departure from Howey is the Supreme Court of California decision in Silver Hills Country Club v. Sobieski. ${ }^{21}$ In that case funds were obtained for the development of a golf and country club by the selling of memberships. It was argued by the promoters that the memberships were purchased for the personal enjoyment of the individuals and not for investment, and therefore the memberships could not be conotrued as an investment contract. In rejecting this argument, the Court enunciated what has become known as the "risk capital" test.

According to this test, and unlike the Howey test, the expectation of a profit or any monetary benefit is immaterial. The objective of securities laws is to afford protection to those who risk their capital whether or not a return on capital is anticipated.

It is submitted that the "risk capital" test adopts a more realistic approach to the definition of security by analyzing the economic features of a given financing device.

The Silver Hills case was further elaborated upon in State Commission of Securities v. Hawaii Market Center, Inc. The Supreme Court of Hawaii held that an investment contract is created whenever:"

(1) an offeree furnishes initial value to an offeror, and

(2) a portion of this initial value is subjected to the risks of the enterprise, and

(3) the furnishing of the initial value is induced by the offeror's promises or representations which give rise to a reasonable understanding that a valuable benefit of some kind, over and above the initial value, will accrue to the offeree as a result of the operation of the enterprise, and

(4) the offeree does not receive the right to exercise practical and actual control over the managerial decisions of the enterprise.

In Pacific Coast Coin Exchange of Conada Limited et al v. Ontario Securities Commission," the leading Canadian case on the definition of investment contract, the Supreme Court of Canada held that the sale of bags of silver coins on margin was an investment contract which involved a trade in securities. Mr. Justice de Grandpre, who wrote the majority decision, applied and refined the Howey test to take into account the circumstances of the Pacific Coast fact situation, and by doing so made a significant contribution to Canadian securities law. In recognizing the criticisms advanced in regard to the Howey test and the vagueness of the phrase "common enterprise", de Grandpre, J. had this to say.2s

In this relationship, the investor's role is limited to the advancement of money, the managerial control over the success of the enterprise being that of the promoter; therein lies the community. In other words the "commonality" necessary for an investment contract is that between the investor and the promoter. There is no need for the enterprise to be common to the investors between themselves.

20. See e.g., Alboini. supra n. 4 at 50.

21. 55 Cal. 2d 811 (1961) (S.C. Calif.).

22. 485 P. $2 d 105$ (1971) (S.C. Hawaii).

23. Id. at 109.

24. [1978] 2 S.C.R. 112.

25. Id. at 126. 
With one fell swoop the common enterprise test has been substantially modified, if not irretrievably scotched.

Mr. Justice de Grandpre was also prepared to apply the risk capital test and conceded that the same result would have been achieved. However, he wanted to adopt a flexible approach to the definition of an investment contract, an approach which would avoid encasing the definition within the straitjacket of the common enterprise or risk capital test as enunciated by U.S. authority. What was crucial to de Grandpre, J. was the policy underlying these tests and not the tests themselves. Be that as it may, the Supreme Court of Canada has perhaps inadvertently allowed the administrators of the securities laws to define a financing device as an investment contract if it is determined that the circumstances warrant such characterizations. ${ }^{25}$ According to de Grandpre, J., it is the legislative policy and not the subsequently formulated judicial test (i.e. Howey and Hawaii) that is decisive. ${ }^{27}$

\section{B. What is a Trade?}

Thus far, the meaning of security has been examined. As aforementioned, the mere fact that a transaction falls within the definition of security is often irrelevant. Only if there is a trade in securities would The Securities Act come into play.

The definition of "trade or trading" in s. 2(1)(31) of the Act has engendered a host of litigation. Like the definition of "security", the definition of trade is extremely broad. The key element of the definition is the requirement of consideration. According to David Johnston, a scholar in this field, before a trade can take place there must be, at least in contemplation, a consideration flowing from each party. ${ }^{20}$ The qualification "in contemplation" means that a trade may occur before consideration has moved from one party to the other, and indeed before there has been a joinder of offer and acceptance. ${ }^{2}$ It is worth noting that the basis of the regulation is "selling" rather than "buying". Registration and, of course, qualification by prospectus, is only required when one person is attempting to sell securities to another. Accordingly, if a course of conduct can be characterized as purchasing rather than selling, it will not attract the operation of the Act.

In the Saskatchewan case of Prudential Trust Company Ltd., et al v. Forseth \& Forseth, ${ }^{30}$ a farmer who had granted an oil lease to Prudential Trust Company later assigned an undivided half interest of all oil rights in the land, subject to the prior lease to Prudential, to Forseth in return for a cash payment. Martland, J. who delivered the juidgment of the Supreme Court of Canada, held that the Saskatchewan Securities Act ${ }^{31}$ did not apply since Forseth's activities involved the purchase of an interest in mineral rights and not the disposition of such interest. The case does suggest, however, that if Forseth had in turn sold his interest to a third party then the Act might have come into play.

In Meyers v. Freeholders Oil Company Limited, ${ }^{32}$ the Supreme Court of Canada held that by offering shares in its capital stock in exchange for the granting of mineral leases, the defendant company was trading in securities.

\section{Sections 6 and 35: the Operative Provisions}

The key provisions of The Securities Act, for our present purposes, are contained in 83. 6 and 35. Section 6 states, in essence: "No person or company shall . . . trade in a security unless such person or company is registered as a dealer, or as a salesman of a registered dealer... and such registration has been made in accordance with this

26. Id. at 132.

27. See Alboini, supra n. 4 at 63.

28. See Johnston, supra n. 4 at 34 .

29. Id.

30. [1960] S.C.R. 210.

31. R.S.S. 1978, c. $5-42$.

32. [1960) S.C.R. 761. 
Act ... . This section applies to brokers, as we generally refer to the securities industry, and requires clearance through the Alberta Securities Commission for each person who proposes to profit by dealings, for commission or fees, in securities. It should be noted that this section also applies to companies issuing securities and so care must be taken to ensure, via the exemptions available in The Securities Act, that clients are not breaching the provisions of the statute.

Section 35 contains the prospectus requirement and provides:

3. 35.(1) No person or company shall trade in a security oither on his own account or on behalf of any other person or company where such trade would be in the course of distribution to the public of such security until there have been filed with the Commission both a preliminary prospectus and a prospectus in respect of the offering of such security and receipts therefor obtained from the Registrar.

\section{What is a "Distribution to the Public"?}

Far more complex than the interpretation of "trade in a security" is the concept of "distribution to the public". The "public" is a vague notion at best, and another example of the draftaman finding comfort in ambiguity. It is worth noting that under the "Closed System" of the new Ontario Securities Act, the concept of "the public" is totally done away with. Nevertheless, under The Alberte Securities Act, the concept of public has at times taken on critical importance. Johnston states that there are at least three views on the interpretation of the "public" in securities legislation:

1. "The first view is that the whole community is the public. Thus every member in a given community unit must be approached before there is a dealing with the public. ${ }^{\text {m3 }}$ Few people take this view seriously.

2. The second view is that any one is the public." Again this view has little to commend itself.

3. The third, and generally accepted view, is that:

The public comprises those members who require the protection of the Act, and thus need the information contained in a prospectus in order to make an informed investment decision. This view is based on two tosts:

(a) the 'need to know' test, which analyzes the state of knowledge about the issuer and the sophistication of the offeree to discover whether he needs prospectus information, or

(b) the 'close personal friend or close business associate' test, which analyzes the relationship between the issuer or its representative and the offeree to discover whether the offeree needs the objective prospectus information and the other protections of the Act."

Under this view, the public could theoretically consist of one person, if that one person has a need to know and thus requires the information contained in a prospectus. Like much of our securities legislation these tests evolved in the case law surrounding the interpretation of the Securities and Exchange Act." In the leading case of SEC v. Ralston Purine Company, ${ }^{37}$ the facts were as follows. Pursuant to a stock investment plan established by the defendant company, securities totalling $\$ 2,000,000$ were sold to employees over a four year period. At issue was whether the sale of these securities constituted a distribution to the public and therefore was required to be qualified by a prospectus. The United States Supreme Court found that while some of the employees who had purchased the shares held relatively senior positions in the company, and were thus acquainted with the operations of the company, there were many other employees, including those employees at the lower levels who had a need to know and therefore required the information contained in a prospectus in order to make an informed judgment. Clark J. said:sa

\footnotetext{
33. Johnston, supra n. 4 at 148.

34. Id.

35. Id.

36. Securities Act of 1933.

37. (1953) 346 U.S. 119 (U.S.C.A. 8th Circuit).

38. Id. at 124-5.
} 
The design of the statute is to protect investors by promoting full disclosure of information thought necessary to informed investment decisions. The natural way to interpret the private offering exemption is in light of the statutory purpose ... the applicability of $\$ 4(1)$ should turn on whether the particular class of persons affected need the protection of the Act.

A leading Canadian decision in this area is $R$. v. Piepgrass." In thet case, a director and officer of a private company sold shares to five people, four of whom had previous dealings with the company. These people were not, however, friends or associates of the accused. The accused director was convicted of trading without registration as a broker, and was unable to fit within one of the exemptions which deals with securities of a private company where the securities are not offered for sale to the public. Mr. Justice MacDonald held: ${ }^{\circ}$

It seems to me that the very essence of a private company envisages the idea that it is of private, domestic concern to the people interested in its formation or in later acquiring shares in it. It is one thing for an individual or group of individuals to disclose information to friends or associates, seeking support for a private company being formed or in existence, pointing out its attractions for investment or speculation as the case may be, but it is quite another thing for a private company to go out on the highways and byways seeking to sell securitieg of the company and particularly by high pressure methods, that is, by breaking down the sales resistance of potential purchasers and inducing them to purchase.

It is clear from the cases and authorities that it is impossible to define with any degree of precision what is meant by the term "offer for sale to the public". It follows that in each instance the Courts will be called upon to determine whether under the particular circumstances there was an offering to the public.

\section{E. Exemptions}

It is evident at this point that the scheme of The Securities Act revolves around the concepts of "security", "trade" and "distribution to the public" and that the goal of securities regulation is, at bottom, protection of the public. The Legislature has recognized that there are certain individuals and certain types of trades which do not require the protection of the legislation and, accordingly, in certain specific instances, has provided exemptions from the provisions thereof. It is not the intention of the writer to outline all of the exemptions available."

There are three general categories of exemptions:

(i) general exemptions solely from the registration requirement of section 6;

(ii) exemptions from the registration requirements as they apply to specified trades or to trades in specified securities; and

(iii) exemptions from the prospectus requirements.

Exemptions of the first category are based on the professional qualifications of the party involved. Thus, a lawyer, accountant or engineer who gives investment advice solely as an incident to the practice of the particular profession is exempt from registering as an adviser. Newspaper, magazine and other business periodical publishers are similarly exempt since the giving of such advice is incidental to the conduct of the business.

The second category of exemptions relates to enumerated categories of trades and securities. The list is long and frequently permits a transaction to be done outside the bounds of The Securities Act.

One such exemption which is frequently relied upon is the isolated trade exemption of s. 19(1)(2). An isolated trade in a specific security by or on behalf of the owner, for the owner's account, is exempt if the trade is not made "in the course of continued and successive transactions of a like nature ${ }^{n}$ and if it is made by a person or company not involved in the business of trading in securities.

\footnotetext{
39. (1959) 29 W.W.R. 218.

40. Id. at 227.

41. For a detailed analysis of this subject, see Peter J. Dey. "Exemptions under the the Securities Act of Ontariu" (1972) Special Lectures of the Lau. Suciety of Upper Cenada at 127.
} 
Devid Johnston states that we have no way of knowing what "isolated" means."2 In other words, what is the appropriate time frame within which to view this exemption? Does the exemption apply only to a one shot deal? What is a trade of a like nature? If a person or company engaged in ten different transactions during the course of a year, would each transaction be an isolated trade? Until this matter is dealt with by the Supreme Court, the confusion surrounding the interpretation of this exemption will continue.

Perhaps the most important exemption provided for in $\mathrm{s.} 19$ is the private placement exemption. Under s. 19(3), and correspondingly, as it relates to the prospectus requirement, s. 58(1)(b), where the purchaser is a person other than an individual, or is a company and purchases securities for investment only and not for resale, and where such securities have an aggregate acquisition cost of not less than $\$ 97,000$, the trade is exempt from both the registration and prospectus requirements.

The frequent use of the private placement exemption has caused concern among the administrators of the various securities acts since this exemption allows companies to bypass the regulatory framework. Nonetheless, the rationale behind this exemption is that the purchaser possesses a degree of sophistication and expertise which makes the protection provided by the Act superfluous.

The category of exemptions from the prospectus requirements are found in 8.58 of The Securities Act, which provides for an enumeration, primarily by cross-reference to 8. 19 of the Act, as to when s. 35 does not apply. The cross-reference tactic is useful as, generally, exemptions apply to both the registration and prospectus requirements. Great care must be taken, however, to ensure that the transaction under consideration fits into an exemption. Most do not.

In addition to the enumerated exemptions of ss. 19 and 35, the Act provides what is in effect a discretionary exemption, based upon the "opinion" of the Alberta Securities Commission. Through s. 59, and the administration thereof, great leniency has been granted to the Commission to take trades and distributions out of the statutory requirements by virtue of opinions or deeming provisions, as follows:

59. (1) Where doubt exists whether a trade proposed or intended to be made in a security would be in the course of a distribution to the public of the security, the Commission may, on its own motion or upon the application of an interested party, determine whether the proposed or intended trade would be in the course of a distribution to the public of the security and rule accordingly.

(2) The Commission, where in its opinion to do so would not be prejudicial to the public interest, upon the application of an interested party may rule that, subject to such terms or conditions as the Commission may impose, a trade or an intended trade in a security shall be deemed not to be a distribution to the public.

(3) Where the Commission determines under subsection (1) or (2) that a trade or an intended trade would not be a distribution to the public of the security, the Commission may rule that registration is not required in respect of such trade.

The use of s. 59, through applications to the Commission, is a popular sport these days as more and more attempts are being made to avoid the cost and delays of the prospectus regime.

\section{QUASI-EQUITY SECURITIES}

\section{A. Joint Ventures}

Joint ventures are not in and of themselves legal entities, but rather a gathering together of individuals or corporations for one specific transaction. Each venturer is independent of the other, and indeed, care must be taken so that the venturers are not treated as partners of a partnership for tax and liability purposes. The assets of the joint venture are owned directly by each of the joint venturers in accordance with their pro-

42. Johnston. supre n. 4 at 123. 
portionate interest. Each joint venturer can claim on his own tax return his share of expenses of the joint venture, and can take depreciation at his leisure rather than according to a group decision.

A joint venture interest may constitute a security within the meaning of The Alberta Securities Act. Either by virtue of the statutory definition of "security" or by virtue of the "investment contract" concept, as expounded by the cases, a joint venture interest may be a security and a company may be in breach of the key operative clauses (ss. 6 and 35) of the Act. Accordingly, each transaction must be viewed in light of the series of questions:

(i) is it a security, in this case?

(ii) is there a trade in the security?

(iii) is the trade exempt from the registration provisions?

(iv) does the trade constitute a distribution to the public?

(v) is there an exemption from the prospectus provisions?

Assuming that it is a security, and that the prospectus and registration requirements of The Securities Act have been breached, what are the consequences? First, by virtue of 89. 136(1) and (4), the company will have committed an offence and be liable to a fine of

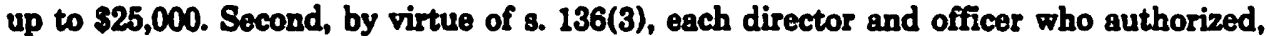
permitted or acquiesced in the offence is liable to a fine of up to $\$ 2,000$, imprisonment for up to one year, or both." Third, the contract may be considered to be voidable by the innocent party, thus enabling him to cancel, $a b$ initio. Fourth, even if the contract is not voidable, by virtue of $\mathrm{s}$. 64, a purchaser has the right to withdraw from the contract for a two day period until 48 hours after receipt of a prospectus. It is submitted that this right exists, at least until lost by the purchaser by action, such as accepting the benefits of the transections, or by affirmation. The effect of this would be to permit an investor to withdraw from a dry hole program, after completion of the drilling.

By way of illustration of the innocent manner in which problems can arise, consider the following real gituation. Mr. A, a geologist, left the company he was with to found a new exploration company. In casual conversation one day, A told B, a close friend, about a well he was proposing to drill and the expected costs. B seid he was interested in investing and had two friends, Doctor $C$ and Doctor $D$, who probably also were interested. A knew noither C nor D. Boing careful, although short on complete instructions, A asked his lawyer to draw up a form of participation agreement he could use to deal with B. The agreement was to vest choice of prospects and all operating decisions in A's company, although the investor would be a working interest owner. The investor was to pay $\$ 6,000$ of his anticipated $\$ 10,000$ share of expenses on execution, $\$ 2,000$ on spudding and $\$ 2,000$ as required. B signed and got $A$ to also execute identical agreements with Doctors C and D. The well was drilled and came up dry. Doctors C and D stopped payment on their last cheques for $\$ 2,000$ each. A paid the bills and then sued $C$ and $D$ for the $\$ 2,000$. $C$ and D sought counsel who advised them to utilize their withdrawal rights under The Securities Act and thus assign their working interests, in the dry hole, back to $A$ and demand their $\$ 8,000$ back. The matter has been settled and all actions discontinued, but it demonstrated the long arm of The Securities Act.

\section{B. Deduction Flow-Through Shares: "66.3 Companies"}

To the writer's knowledge, no term has developed yet within the financial community that has achieved acceptance as a shorthand way of describing this particular technique of raising quasi-equity. The Income $\operatorname{Tax} A c t$, by virtue of s8. 66.1(6)(a)(v) and 66.2(5)(a)(v), provides that where a taxpayer incurs Canedian exploration expense ("CEE") or Canadian development expense ("CDE"), for the benefit of a corporation pursuant to a written agreement with the corporation solely in consideration of the issue to him of treasury shares of that corporation, the expenses are deductible by the taxpayer as CEE or CDE, as if incurred solely by him. Section 66.3 of the Income Tax Act provides

43. Note that the statute does not contemplate fines or imprisonment of couneel. 
that shares received by an investor in such circumstances are deemed to be inventory in the hands of the investor, rather than capital property as shares ordinarily would be, and are deemed to be acquired at a cost of nil. Thus the concept is one of incurring drilling for shares and the scheme may be codeworded as "66.3 shares" or a "66.3 company". Several points, relating to both tax and securities matters, should be raised regarding $66.3 \mathrm{com}$ panies.

\section{No Limited Liability}

Since the investor must actually incur the CEE or CDE expense, he is liable, or potentially liable, for damage caused, and must be protected by adequate insurance or indemnities or both. Two further thoughts on this point relate to disclosure and extent of exposure. To the extent that an investor is without limited liability, adequate disclosure of this fact must be made in the prospectus. The lack of limited liability status is extraordinary in the context of distributions of shares, and, accordingly, a high standard of disclosure is applicable. As to the extent of exposure, there are several issues that can be raised. Who may be responsible to whom, and for what? Although the drilling contractor is being paid by the investor, the contract is with the 66.3 company, being the working interest owner. Assuming the responsible selection of the drilling contractor, does the independent contractor status thereof protect the investors or is there any agency relationship between them? Although the deductions flow through to the investor in these drilling for share deals, who is liable to third parties for damage off the site (Farmer Brown's cows, for example)?

\section{Ongoing Entity}

66.3 companies suffer, in the writer's observation of the formulation thereof and the marketing of their shares, from the burden of prospectivity. Limited partnerships are desigmed, marketed and financed as single purpose ventures which have a strong introspective nature; that is, funds are raised to participate in a series of wells on a finite group of prospects, following which, except for any step-out work, the business nature of the partnership terminates and the partnership produces oil and gas from these prospects, and then dies. 66.3 companies start out the same way; that is, with an infusion of capital and a basic exploration program that is tied to one or more active exploration companies. The problem is that once the funds are spent, a corporation, needing management and financing, is in place - and must be dealt with.

\section{Inefficiency}

The ability to flow the tax deductions back through to investors results in $66.3 \mathrm{com}$ panies being somewhat inefficient from a tax viewpoint. In a limited partnership, all items relating to the CEE and CDE accounts and to resource income flow through to the partners. Thus, on the disposition by a partnership of an interest in a producing well, a Canadian resource property, the recapture in the CDE account flows through to the partners and ahy balance in that account is available for use against the sale proceeds. Similarly, resource profits flow through to the partners who, because of the flow through of CEE and CDE, have earned depletion available to shelter some of the resource income. In a 66.3 company, the CDE is separated from the property with the consequence that, on a property disposition, the company lacks a CDE base with which to shelter proceeds of sale. In addition, the CEE and CDE are separated from the resource income so that the resource income accrues to the company which lackes earned depletion to shelter some of that income from tax, while the shareholders/investors may have no resource income from other sources $s 0$ as to be able to gainfully utilize the eamed depletion. It is interesting to note that the Rangeco financing attempted to deal with this latter problem by providing the investors with a temporary royalty interest which was designed to produce resource income against which the earned depletion could be used. While this attempt should be applauded as a drafting and tax planning mechanism, it made the Rangeco deal more difficult to sell because of the substantial added complexity. 


\section{Tax Inequity}

As stated above, the Income Tar Act provides that 66.3 shares are deemed to be inventory of the tarpayer acquired at a cast of nil. The effect of this is that upon a saie of such shares, the entire proceeds are tarable as ordinary income. This results in a clear inequity for the investor. For example, assume the investor incurred $\$ 100$ of CEE and received one common share of a new company, Company X. He deducts $\$ 100$ from income. Now assume the value of the ghare rises to $\$ 200$ and it is sold. The entire $\$ 200$ will be treated as tarable income even though only $\$ 100$ was deducted from income. To avoid this result, a company could use a variation of the "estate freeze" concept. In its simplest form, this is as follows. The investor's $\$ 100$ would be appropriated: $\$ 1$ to acquire 1 common share of Company $X$ and $\$ 99$ to incur $\$ 99$ of CEE in exchange for 1 preferred share of Company X redeemable at $\$ 99$. Since the preferred share can be redeemed for $\$ 99$, its fair market value, ignoring the economic effect of the rate of dividend paid on the share, cannot exceed \$99. Therefore, the residual value will lie with the common share, so that on a sele of the two shares for $\$ 99$ and $\$ 101$ respectively, there will be $\$ 99$ of ordinary income allocable to the preferred share and $\$ 100$ of capital gain allocable to the common share.

\section{Limited Partnerships}

The limited partnership form of organization serves extremely well to permit the raising of "quasi-equity". The investors participate, with limited liability, in the oil and gas industry, while receiving the flow through to them of the tax deductions for certain costs and expenses incurred by the partnership in its business operations. In return for these benefits and the advantage of receiving professional management of their money, and at the additional cost of giving up a say in the management of the partnership, the investors are promoted, that is, they will receive a smaller interest in the revenues or equity of the wells than that which they pay for. This promotion really is what creates the quasi-equity for the operator/promoter. Note that there really are three roles: operator, general partner and limited partners. In some partnership deals, the distinction between operator and general partner is maintained and three distinct parties fill the roles. The Aurora-Czar deals"s are an example of this, where Aurora Energy Fund Ltd. acts as general partner of a limited partnership which then joint ventures with Czar Resources Ltd. which is the operating oil and gas company. In other deals, the distinction between operator and general partner is maintained, but the same company serves both roles. An example is the new Northstar drilling fund, ${ }^{\infty}$ where Northstar acts as the general partner of a limited partnership which then joint ventures with Northstar, acting as operator. The third format has the roles of operator and general partner merged under the partnership agreement which then covers not only the partnership arrangement but also the operating aspects of the deal. An ezample of this is the Wainoco deals." The basic difference between these latter two formats is whether the promoter/operator ends up with an interest in properties, as it would under the Northstar type formulation, and thus has a right to deal with its assets independently, or with an interest in a partnership, as it would under the Wainoco approach. Whatever the format, the partnership vehicle provides the promoter/operator with a base of risk capital with which to work and for which it is responsible es to deployment and management. This is like equity to the promoter/operator, except that someone else retains title; hence the term "quesi-equity".

The raising of capital through limited partnerships has now become big business. Many companies are using partnerships as a primary source of funding for their exploration programs and many deals are being done. The high profile deals are the public filings where a prospectus is involved. The medium profile deals usually are done on a private placement basis, with the units placed by virtue of an exempting order obtained

4. The Partnership Act, R.S.A. 1970, c. 271, as am., g. 63.

45. Aurora-C2ar 80-81 Energy Program, prospectus dated April 18, 1980.

46. Northstar Resources 80-81 prospectus dated May 21, 1980.

47. Wainocu 80 Cansda. prospectus dated April 18, 1980. 
from the Alberta Securities Commission. The low profile deals are done without contact with the Commission and in most cases without acknowledgement of The Securities Act, or with the attitude that the Act could not possibly apply.

Whether limited partnership units are securities and whether the sale of them involves trading within the meaning of The Securities Act seems to the writer to be beyond question. The tests of "instrument commonly known as a security" or investment contract are met and, in view of the recent strengthening of the enforcement and investigation side of the Alberta Securities Commission, our clients should be advised to proceod cautiously when raising funds in this fashion.

Before reviewing specific considerations regarding limited partnerships, there are two points to be made about public, that is prospectus, offerings of partnership units. The first is that counsel and the clients must recognize the scope of the task. A prospectus must constitute full, true and plain disclosure of all material facts relating to the securities offered thereby. Thus, the prospectus is a description of the issuer and the securities, a task which can range from updating past documentation on consistent, easily described companies, such as Calgary Power Ltd., to attempting to grab a momentary picture of a moving target, such as documenting the affairs of Dome Petroleum or Alberta Gas Trunk Line. Limited partnership prospectuses have a double element. Not only are the operator and the torms of the deal with the partnership described, but at the same time the now entity is being created (the partnership) and being put into business.

The second point is that the Alberta Securities Commission seeks not only to ensure disclosure, but also intends to be involved in the substantive aspects of the transaction. Through its Policy No. 3-19," the Alberta Securities Commission has set minimum standards for both disclosure matters and substantive matters in "drilling programs", as they are called therein. Although its recent proposed amendments to the policy call for a backing down somewhat from the regulation of the deal rather than the disclosure of the deal, the Alberta Securities Commission is still attempting to regulate several business items. Therefore, it is important to review this policy and published statements thereon at the time of formulating a deal.

\section{Economic Evaluation of Drilling Programs}

Notwithstanding the tax factors and potential tax shelter, an investor should be aware that the prime considerations in making an investment in a drilling program should be the same as for any other investment: economics. Sufficient disclosure must be made in the prospectuss of all factors relating to the properties or prospects (if predesignated), the expected capital requirements for the program, the specific objectives and purposes of the specific program and current industry economic conditions. Care should also be taken to provide the assumptions underlying property reports and to explain that the discounted cash flow figures presented for properties or for prior programs are before-tax numbers, not after-tax. Here, a heavier burden than normal falls upon counsel, for as yet neither our iseuers nor our underwriters have the experience to judge materiality/immateriality in the drilling program context.

\section{Conflicts of Interest}

Because the manager of an oil and gas drilling fund is normally involved in the oil and gas business for his own account in other ventures and perhaps as a manager in other drilling funds, a conflict of interest may inevitably result between a particular program and the manager. Policy 3-19 provides that a manager or his affiliates are restricted from entering into certain transactions during the course of a particular program."

The manner in which a manager will handle potential conflicts of interest is normally outlined in the prospectus. An investor, although he may be comforted by the provisions

48. The Alberta Securities Commission, Guidelines for the Filing of a Prospectus for Oil and Gas Prokrams (hereinafler referred to as "Policy 3-19").

49. Id. at VIII (g)(1) and (2). 
of Policy 3-19 and the fact that the manager would probably not prejudice his reputation, should nevertheless carefully review this section of the prospectus to see what potential areas of conflict exist and how they will be handled.

From a practical viewpoint, the solution to the whole area of conflicts of interest lies in the selection of a high quality program manager. In the majority of instances, the investor can reasonably assume that a manager with impeccable credentials will not damage his reputation solely to raise monies for a drilling program.

\section{Additional Assessments/"Overcalls"}

A serious problem of drilling programs using the limited partnership format is the inability to resdily raise further capital once the initial capital contributions of the investors have been expended or committed to be expended. Unlike corporate vehicles, which can issue further shares to raise additional capital, ${ }^{\infty}$ limited partnerships face many hurdles in subsequent offerings, not the least of which is the valuation of the Units. To overcome this, many public limited partnership drilling programs provide, at the time of formation of the partnership and at the time of the initial public offering, a mechanism to facilitate the subsequent raising of equity capital. Some examples are set forth below:

(a) Program basis voluntary additional assessment - The general partner may call upon the limited partners to contribute up to $\$ X$ per Unit ${ }^{\text {t1 }}$ to be used for drilling development wells, for completion costs, for acquisition of additional, adjoining acreage and for procesaing plents and equivalent facilities. The call for funds must be accompanied by the same type of material as a corporation sends to its shareholders when it has a rights offeringss and must conform in its default provisions to the dictates of Policy 3-19.4 Additionally, it would seem reasonable to provide that the general partner, at the time that it calls for the additional assessment, should advise the limited partners as to whether it shall make the additional contribution with respect to Units held by it.se

(b) Well by well basis voluntary additional assessment - After the initial capital of the limited partnership has been expended or committed, the partnership may undertake additional operations to more fully explore and develop properties acquired by the limited partnership during its initial phsse. As to each such additional operation for which additional assessments are required, the general partner will give written notice to the limited partners advising them of the nature and purpose of the operation, the effect of not participating in the subsequent operation, available pertinent geological data and each individual limited partner's pro rata share of the expenditure necessary to finance the operation. Limited partners may elect, as to each operation or on a blanket basis for all operations, whether or not to participate. Limited partners who elect to participate are therearter billed periodically for their pro rata share of expenditures for each subsequent operation. The aggregate of such additional assessments is limited to $90 \%$ of initial capital. However, the limited partnership agreement provides for the increasing of that ceiling by amendment of the agreement. 4

(c) Program basis additional assessments: (sale of additional units) - as required To accommodate the accounting problems caused by additional assessments, to standardize each Unit within a program and to provide for easy subdivision of Units

50. See in this regard the recent offering of Rangeco Oil and Gas Ltd., a 1977 company financed with 66.3 shares.

51. Policy 3-19, supra n. 48 at VIII (f)(1), which sets this at a maximum of 100 ". of initial subscriptions.

52. The Securities Act, supre n. 5. s. 19(1)(8)(iii); Uniform Act Policy 2-05, as published by securities adminis. trators of the Uniform Act provinces.

53. Policy 3-19, supre n. 48 at VIII (f)(2).

54. For an example of this type of provision, see the prospectus of Shelter Hydrocarbons 78-I. dated June 12. 1978.

55. Fot an example of this type of provision, see the Registration Statement of Woods 1979 Drilling Program, as filed with the Securities and Exchange Commission on April 19, 1979. 
for trading purposes, one program has used a $\$ 100$ Unit size and is prepared to issue non-transferable rights to acquire additional units, when additional fundo are required, at $\$ 100$ per Unit.s

(d) Program basis additional assessments: (sale of additional units) - calendar basis - In anticipation of funds to be required in subsequent years, one program has included rights to subscribe for additional units in future years as an attribute of the units being sold under the prospectuss. 37

Policy 3-19 regulates permissible "penalties" for default in assessments, distinguishing between voluntary assessments and mendatory assessments. ${ }^{38}$

\section{Liquidity}

A principle drawback to most drilling programs, from an investor's viewpoint, is the fact that the purchased security is an illiquid investment, i.e. there is no formal market for it. Thus, the investor is in many instances incapable of realizing on his investment other than by waiting out the term and receiving his return in the form of annual distributions of net production revenues. The drilling program industry has recognized this detrimental aspoct of their product and has devised a number of alternative formulations to permit an investor, at a price, to liquidate his investment. One disadvantage inherent in the methods of attaining liquidity is that the method of determining the price at which the investor's units or the partnership's assets are disposed of involves an estimate of reserves; and it is likely that estimates of reserves in the initial years will be derived from preliminary information which may vary (most likely upwards) in future years. Thus investors who exercise their rights during the first few years run the risk of having sold out at prices which reflect immature, rather than mature, property values. Methods that have been used to provide liquidity include the following:

(a) Retirement of limited partners (redemption of units) - The sponsor/promoter (or a third party) agrees to purchase, on a predetermined formula, assets from the limited partnership. The limited partnership then allocates the proceeds of sale to those limited partners who wish to retire and pays them their proportional share of such proceeds received." Note that on this basis, the asset purchaser acquires assets for which he can take a deduction for tax purposes and the retiring limited partner, by being allocated a portion of the proceeds to the limited partnership of the disposition, "recaptures" deductions otherwise available to him.

(b) Purchase of units - The sponsor/promoter agrees to purchase, again on a predetermined basis, limited partnership units from limited partners. ${ }^{\circ}$ Note that there the limited partner preserves his deductions and has disposed of capital property while the purchaser, on buying capital assets, has no deductions available to him.

(c) Listing of 66.3 shares - The Rangeco Oil and Gas Ltd. program was the first public program offering structured to use flow-through shares. While there was no initial commitment to do so, the issue contemplated achieving liquidity by listing the common shares. The shares have now been listed and thus the investor can dispose of that portion of his investment in the stock market, normally deriving a capital gain.

(d) Roll-over for shares - The limited partnership agreement provides that the general partner, with the concurrence of a specified percentage of limited partners, can cause the limited partnership and all limited partners to effect a roll-over of the limited partnership into a corporation; all on a tax-free basis. Presumably, then an offer is made by a listed company for a share exchange or some other arrangement 80 as to provide liquidity for the new shares."

\footnotetext{
56. See Northatar Resources 79-80 prospectus dated June 27, 1979.

57. See KanAmera Oil and Gas Program, prospectus dated July 5, 1979.

58. Supra n 48 at VII (f)(2).

59. See e.g., Shelter Hydrocarbons 78-I, dated June 12, 1978.

60. See e.8., Wainoco 79 Canada, dated June 20, 1979.

61. See e.8., Canadian Oil and Gas Fund (1975) dated June 15, 1976, and the preliminary prospectus, dated March 31. 1880, for Chess-Clarion 1980-81 Exploration Program.
} 


\section{Transfers}

In addition to the problems accompanying the fact of being illiquid investments, the trangfer of limitod partnership units carries certain specialized concerns. The first is that under The Partnership Act, " a trangferee does not become a limited partner until the certificate of limited partnership has been amended in accordance with s. 69 thereof. Thus, to receive the benefit of the flow through of deductions under the Income Tax Act by being a partner of the limited partnership at the end of its fiscal period"s the transferee must ensure that the appropriate registrations are timely made.

If a limited partner transfers his interest in mid-year, then he gets no deduction for his share of CEE and CDE incurred to the date of sale, since he was not a partner at the end of the fiscal year of the limited partnership. Quaere whether the transferee gets same as his share of "any expense incurred by him". While there is some doubt, the limited partnership agreement should expressly state that such share of income, losses and expenses is allocated to the transferee in the event of a transfer.

\section{Foreign Investment Review Act}

The Foreign Investment Review Act" provides that the "acquisition of control of a Canadian business enterprise" or the "establishment of a new business in Canada" by a "non-eligible person" or by a "group of persons any member of which is a non-eligible person" is a reviewable transaction for which notice must be given to the Foreign Investment Review Agency. [Emphasis added.] To the extent that the operations and activities carried on by a limited partnership constitute a new business, then, especially in view of the time delays involved in processing notices through the Agency, steps must be taken to avoid making such activities reviewable. Three possibilities present them. selves.

(a) Sell only to Canadians - Assuming the general partner is not a "non-eligible", then this approach avoids FIRA. While simple in theory, this approach must be rejected in practice for there is no way of administering or policing it. Even if the underwriter were to take a certificate from each purchaser, no absolute protection is offered, for the Foreign Investment Review Act deals only with the facts and makes no exception for false certificates.

(b) Pre-form the limited partnership - If at the time of preparing and filing the preliminary prospectus the limited partnership is formed with the general partner and one limited partner, both of whom are not "non-eligible", then all activities and actions thereafter can be considered those of the limited partnership, with the consequence that the establishment of a new business has been effected only by "eligibles". Thereafter, the admisaion of additional limited partners will have no bearing because of the fact that, by their very nature, limited partners do not acquire control.4

(c) Provide for no employees - Section 3(4) of the Foreign Investment Review Act provides that a business is established in Canada only when employees thereof report for work to an establishment in Canada. Consequently, if the limited partnership never has employees, it never establishes a business." Note that this approach rejects, and probably rightly 80 , the "attribution of employees" theory utilized by the staff of the Foreign Investment Review Agency in determining whether or not transactions are reviewable.

7. "Disclosure" v. "Blue Sky"

Federal securities regulation in the United States, principally through the Securities Act of 1933," is based upon the premise that complete, accurate and comprehensible dis-

62. R.S.A. 1970, c. 271, as am.

63. R.S.C. 1970, c. 1-5, as am., s. 66.1(6)(a)(iv) for CEE and s. 66.2(5)(a)(iv) for CDE.

64. S.C. $1973-74$, c. $46,8.8$.

65. See e.8. Northstar Resources 80-81 prospectus daced May 21, 1980.

66. See e.g. Wainoco 79 Canada prospectus deted June 20, 1979.

67. Supra n. 36. 
closure is what investors require to make an informed investments decision and that it is not for the government to interfere with the economic considerations underlying the transection or being interposed between the issuer and the investor. The securities legislation of the various states, however, derives as much from the regulation premise as from the disclosure premise.

Securities legislation in Canada combines the "blue sky" aspects with the call for disclosure to investors. Thus, while The Securities Act and the Regulations mandate certain disclosure items and formats for inclusion or exposition in a prospectus, the acceptance of the prospectus and the issuance of a receipt is a matter of discretion." In Voyager Explorations v. Ontario Securities Commission," the court stated: ". . . the Commission exercises the function of an administration body and not of a judicial body when it accopts a prospectus and issues a receipt therefor".

Bill 76, the Alberta proposal for a new securities act, like the new Ontario Act, adds several additional statutory provisions to this "blue sky" aspect. Section 58(1) of Bill 76 continues the language of section 61(1) of the present Act with respect to the discretion of the Director regarding prospectus receipts: "The Director may in his discretion direct the Registrar to issue a receipt for any prospectus filed under this part unless .... . Under the present Act, the recoipt, discretionary anyway, is held back if it appears to the Director that one of the enumerated things has happened. Under s. 58(1) of Bill 76, the receipt, discretionary anyway, is held back if it "appears to [the Director] that it is not in the public interest to do $80^{\prime \prime}$. In addition, under Bill 76, in specified instances, the Director may not approve the issuance of a receipt. By contrast, the corresponding section of the new Ontario Securities Act'o purports to take away some of the Director's discretion. Section 60(1) states that, subject to specific enumerations, "the Director shall issue a recoipt for a prospectus filed under this Part unless it appears to him that it is not in the public interest to do $80^{n}$. While these new provisions in Alberta do not, and in Ontario may not, substantially alter the present discretion on the issuance of a receipt for a final proepectus, it is interesting to note that three new statutory factors have been added whereby the Director loses his discretion and may not issue a receipt."

The Alberta Securities Act now provides that an issuer must be given the opportunity to be heard before the refusal to issue a receipt for a prospectus is finalized." The hearing is before the Commission rather than the staff, a fact which can be an interesting tool in last minute "deficiency showdowns". This provision is continued under s. 58(3) of Bill 76. In addition, Bill 76 adds a new provision, whereby the Director may refer a "material question involving the public interest" under s. 58(1) or a "new or novel question of interpretation" under s. 58(2) to the Commission for a determination. The issuer has the right to appeal an adverse decision of the Commission to the Court of Queen's Bench.

Anticipating Bill 76, the Alberta Securities Commission has already begun implementing this new procedure by way of informal hearings on specific points. Generally, these hearings appear to be well received by the various parties, for they permit an expeditious resolution to problems which have become major stumbling blocks as between counsel and the commission staff.

Accepting for now, as our legislature in its wisdom says we must, the blue-sky nature of our provincial securities administration, the writer still has two main concerns with the manner in which the securities regulators deal with drilling programs.

68. The Securities Act, supre n. 5 at 3. 61(1).

69. [1970] 1 O.R. 237 at 244. See also, G. Emerson, "Vendor Beware: The lssue and Sale of Securities" (1979) 57 Can. Bar Rev. 213; "Shoppers Investment Ltd." (1972) O.S.C. Bulletin 215; "Galaxy Gold Mines" (1975) O.S.C. Bulletin 97; and J. Cowan. The Discretion of the Director of the Ontario Securities Commission" (1975) 13 O.H.L.J. 735.

70. S.0. 1978, c. 47.

71. Id. at so. 60(2)(d), (e) and (i), and Bill 76, ss. 58(2)(d), (e) and (i).

72. Supra n. 5 at s. $61(2)$. 
(a) No precedent value - Once decisions to accept deviations from Policy 3-19 have been made, whether as a result of pre-filing conferences, the deficiency clearance process or the informal hearing process, why must they then be ignored? Letters from staff, telezes from staff and decisions from the Commission all refer to "on this specific occasion". The dictate of precedents, and the consequent extrapolation from them, is a principal part of what is learned in law school, and of how lawyers think and analyze. Yet how can lawyers advise their clients regarding the commercial certainty of doing business in Alberta? And what does the Commission do when faced with the same problem with the same issuer next year?

(b) Stifling creativity - The drilling program "industry" is still very young and some lawyers are having a good deal of fun with the challenge of developing new twists or gimmicks or of adopting existing ones to new vehicles. Yet the dictates of administering and following a semi-rigorous administrative program, like Policy 3-19, tends to stifle imagination and innovation. Drilling programs have the potential to be an important source of quasi-equity financing for the oil industry, and care should be taken to encourage, not discourage their development. 